\title{
Gradual retirement, financial incentives, and labour supply of older workers: Evidence from a stated preference analysis
}

\author{
Citation for published version (APA):
}

Elsayed, A. E. A., de Grip, A., Fouarge, D., \& Montizaan, R. M. (2015). Gradual retirement, financial incentives, and labour supply of older workers: Evidence from a stated preference analysis. Maastricht University, Graduate School of Business and Economics. GSBE Research Memoranda No. 030 https://doi.org/10.26481/umagsb.2015030

Document status and date:

Published: 01/01/2015

DOI:

10.26481/umagsb.2015030

Document Version:

Publisher's PDF, also known as Version of record

\section{Please check the document version of this publication:}

- A submitted manuscript is the version of the article upon submission and before peer-review. There can be important differences between the submitted version and the official published version of record. People interested in the research are advised to contact the author for the final version of the publication, or visit the DOI to the publisher's website.

- The final author version and the galley proof are versions of the publication after peer review.

- The final published version features the final layout of the paper including the volume, issue and page numbers.

Link to publication

\footnotetext{
General rights rights.

- You may freely distribute the URL identifying the publication in the public portal. please follow below link for the End User Agreement:

www.umlib.nl/taverne-license

Take down policy

If you believe that this document breaches copyright please contact us at:

repository@maastrichtuniversity.nl

providing details and we will investigate your claim.
}

Copyright and moral rights for the publications made accessible in the public portal are retained by the authors and/or other copyright owners and it is a condition of accessing publications that users recognise and abide by the legal requirements associated with these

- Users may download and print one copy of any publication from the public portal for the purpose of private study or research.

- You may not further distribute the material or use it for any profit-making activity or commercial gain

If the publication is distributed under the terms of Article $25 \mathrm{fa}$ of the Dutch Copyright Act, indicated by the "Taverne" license above, 
Ahmed Elsayed, Andries de Grip, Didier Fouarge,

Raymond Montizaan

Gradual Retirement, Financial Incentives, and Labour Supply of Older Workers: Evidence from a Stated Preference Analysis

RM/15/030

\section{GSBE}

Maastricht University School of Business and Economics

Graduate School of Business and Economics

P.O Box 616

NL- 6200 MD Maastricht

The Netherlands 


\title{
Gradual Retirement, Financial Incentives, and Labour Supply of Older Workers: Evidence from a Stated Preference Analysis
}

\author{
Ahmed Elsayed $^{* 1,2}$, Andries de Grip ${ }^{1,2,3}$, Didier Fouarge $e^{2,3}$, Raymond Montizaan ${ }^{1,2,3}$ \\ ${ }^{1}$ IZA, Bonn, Germany \\ ${ }^{2}$ ROA, Maastricht University \\ ${ }^{3}$ Netspar
}

September 2015

\begin{abstract}
Using data from a stated preferences experiment in the Netherlands, we find that replacing full-time pension schemes with schemes that offer gradual retirement opportunities induce workers to retire one year later on average. Total life-time labour supply, however, decreases with 3.4 months because the positive effect of delayed retirement on labour supply is cancelled out by the reduction in working hours before full retirement. The impact of gradual retirement schemes is, however, heterogeneous across groups of workers. Workers with nonroutine job tasks retire at a later age when they can gradually retire. Financial incentives, either in terms of changing pension income or the price of leisure, also affect the expected retirement age, but the impact of these financial incentives does not differ with the possibility of gradual retirement. Finally, we find that gradual retirement is not a preferred option among workers as the large majority still prefers full retirement. This especially holds for workers with a lower wage and those with higher life expectancy.
\end{abstract}

JEL Classification: J14, J26

Key words: gradual retirement, labour supply, financial incentives

\footnotetext{
* Corresponding author at: Institute for the Study of Labor (IZA), Schaumburg-Lippe-Strasse 5-9, 53113 Bonn, Germany. Phone: +49 (228) 3894-161; Fax: +49 (228) 3894-510; E-Mail: elsayed@iza.org

We acknowledge the comments and suggestions of Hans Bloemen, Marion Collewet, Arjan Non, the participants at the Fourth SOLE/EALE World Conference, Montreal, Canada, and the Pension Day Workshop, Utrecht, the Netherlands.
} 


\section{Introduction}

As a result of population ageing and declining fertility, many industrialized countries with 'pay-as-you-go' pension systems face a steady decrease in the ratio of contributing workers to inactive retirees who draw from these schemes. These unfunded systems will become financially unsustainable unless labour supply of older workers or productivity increases fast enough to compensate for the negative demographics. Most industrialized countries have therefore already started to implement major pension reforms aimed at increasing the labour supply of older workers. These reforms include, among others, decreases in the generosity of pension benefits and increases in the eligibility age for early and statutory retirement (Gruber and Wise 1998; Duval 2005; Mastrobuoni 2009; Kangas et al. 2010; Börsch-Supan 2012; Staubli and Zweimüller 2013). In addition, in several countries gradual retirement schemes have been introduced, whereby workers do not end their career abruptly but rather in a stepwise fashion (Reday-Mulvey 2000; Warren 2015). This could enable workers to extend their working life with a lower workload. ${ }^{2}$

Existing literature stresses that the introduction of gradual retirement schemes can have major benefits both at the micro and the macro level (Kantarci and Van Soest 2008). At the micro level, gradual-retirement schemes can improve life time utility as they introduce the possibility to avoid a pension shock following an abrupt transition from full-time work to full-time retirement, and extend the choice set of older workers (Reday-Mulvey and Delsen

\footnotetext{
${ }^{2}$ In the past two decades, gradual retirement schemes were first adopted in combination with early retirement programs and were only later introduced as an alternative instrument to reduce complete early withdrawal from the labor market. Sweden was one of the first countries to adapt a gradual scheme in 1976. In Denmark, a reform in 1987 aimed to promote gradual retirement by replacing the system of full early retirement with a parttime work regime. In Finland, a partial retirement scheme was introduced for wage earners aged 60 or older in the late 1980s, which was extended in the 1990s to workers aged 56 or older and was further stimulated by additional incentives (e.g., tax breaks for firms). Germany, Austria, France, Belgium, and the Netherlands now also offer the option to enter gradual or partial retirement before or after the standard retirement age. Also outside Europe gradual retirement schemes have been introduced. For example, the Australian government stimulated gradual retirement transitions by introducing "transition to retirement" pensions in 2005, which allow older workers to reduce their working hours and access part of their superannuation savings in the form of a pension to supplement their labour income (Warren 2015).
} 
1996; Reday-Mulvey 2000). Gradual retirement may reduce the burden of work, and thereby reduce work-related stress and increase employee morale, enabling workers to keep working beyond an age at which they would otherwise have fully retired (Kantarci and Van Soest 2008). Finally, at the macro level, it is claimed that gradual retirement schemes may increase the retirement age by facilitating work after the effective retirement age and therefore restrain early withdrawal from the labour market provided the introduction of these schemes is accompanied by a pension scheme with the right financial incentives. This would enhance the financial sustainability of current pension schemes. Gradual retirement may, however, also lead to a reduction in total labour supply when workers engage in early part-time retirement, while they otherwise would have chosen to continue to work on a full-time basis. The total effect on labour supply therefore depends on which of these two effects is the largest, making the net effect of gradual retirement schemes on total labour supply ambiguous. This raises the question to what extent the introduction of gradual retirement opportunities actually stimulates workers to continue working, and to what extent it can be expected to increase total labour supply. The next question is whether the effects differ with the financial incentives provided by the pension system to postpone retirement.

This paper uses a stated preference approach to study the impact of a gradual retirement scheme on the expected retirement age and total labour supply of Dutch public sector workers. We furthermore investigate whether the effects differ with the financial incentives provided by the pension system, and explore the heterogeneity in the impact of the introduction of gradual retirement opportunities on retirement preferences of workers with different personal and job characteristics. Our stated preference approach consists of six vignettes in which respondents get hypothetical (but realistic) retirement scenarios that either involve gradual or full retirement and vary in terms of financial incentives (either in terms of changing the price of leisure or in terms of changing pension income). Respondents are asked 
to indicate at what age they would retire, and are subsequently asked to compare and rank the preferred choices they made when confronted with the different scenarios. The main reason why we use a stated rather than revealed preferences approach is that we want to estimate preferences for pension plans which do not yet exist or to which many workers so far do not have access. ${ }^{3}$ Moreover, the vignette design ensures that the choice alternatives are known to the researcher, and that the variation in choices is sufficiently large and by construction exogenous to preferences. ${ }^{4}$ Because of this exogenous variation, the estimated effects are likely to be causal.

We find that the replacement of full-time retirement schemes with a gradual retirement scheme stimulates workers to retire, on average, one year later. Nevertheless, total labour supply significantly decreases by 3.4 months when workers have the gradual retirement option, as the positive effect of delayed retirement on labour supply is cancelled out by the reduction of working hours preceding full retirement. The impact of the introduction of gradual retirement schemes is, however, heterogeneous across groups of workers. In particular, workers with non-routine job tasks are inclined to retire later (and increase their overall labour supply) when they have the possibility to gradually retire. We furthermore show that the positive impact of financial incentives to postpone retirement on workers' retirement expectations does not differ between gradual and full retirement options. Finally, our ranking analysis of workers' preference for the different scenarios shows that

\footnotetext{
${ }^{3}$ Most previous studies focused on actual retirement decisions and suggested that the introduction of gradual retirement schemes could indeed lead to a postponement of retirement, although the effects on total labour supply are small or non-existent (e.g., Gustman and Steinmeier 2004; Gielen 2009; Machado and Portela 2012). However, since these studies focus on actual retirement decisions they do not identify all retirement options which were available to older workers, because the options that are not chosen cannot be observed, or because it is not even clear which options workers would have chosen when they would have had the opportunity to choose (Kantarci and Van Soest 2008 2013). The latter is particularly relevant for studies on the impact of gradual retirement plans, since it is often unclear whether employers offer such a plan, and, if they do, which trajectory of earnings and pension incomes a plan offers. This especially holds because gradual retirement arrangements are often based on informal agreements negotiated between an employee and his/her employer (Hutchens 2010). Our stated preferences approach circumvents this type of problem.

${ }^{4}$ This method is extensively used in marketing research (see, for example, Louviere et al. 2002) and is gaining quickly ground in economics (see, for example, Barsky et al. 1997, Revelt and Train 1998; and, specifically for labour supply, Kimball and Shapiro 2010; Van Soest and Vonkova 2014).
} 
gradual retirement is not a preferred option among workers as the large majority still prefers full retirement. In particular, workers with a lower wage and a higher life expectancy rank the gradual retirement scenario lower. Our results therefore suggest that the introduction of gradual retirement opportunities in the Netherlands would not contribute to a further increase in labour supply.

We contribute to the existing literature on gradual retirement and labour supply of older workers in three important ways. Firstly, this paper is the first to study the causal link between the introduction of gradual retirement opportunities on total labour supply. Only a few studies have investigated the relationship between flexible work hours and older workers' total labour supply providing mixed evidence. While Gustman and Steinmeier (2004) found that the abolishment of minimum hours constraints would result in a small net increase in full-time equivalent employment, Gielen (2009) and Machado and Portela (2012) found explorative suggestive evidence that total labour supply of older workers may even decrease when flexibility in work hours would increase. Secondly, this paper builds on two related studies of Van Soest et al. (2007) and Kantarci and Van Soest (2013). These studies used stated preferences experiments that show that many workers could be convinced to work part-time if they are given fair financial compensation, but also that many workers are more likely to choose full-time retirement over partial retirement. ${ }^{5}$ Our study differs from these studies because we not only study the impact of gradual retirement on retirement expectations, but also its net impact on total labour supply. Moreover, a great advantage of our study is that the base scheme in our stated preference experiment is similar to the actual pension scheme of public sector workers in the Netherlands allowing for more realistic estimates of the effects of gradual retirement opportunities on the labour supply of older

\footnotetext{
5 Stated preference experiments have also been used in retirement studies which did not focus on gradual retirement (e.g., Van Soest and Vonkova 2014).
} 
workers. ${ }^{6}$ Thirdly, we go beyond previous studies by showing that the introduction of gradual retirement schemes has heterogeneous effects on the retirement age and labour supply of different groups of workers, depending on their personal and job characteristics.

\section{Data and experimental design}

\section{Data collection}

For this study, the public sector's pension fund provided us with 13,151 randomly selected email addresses of Dutch public sector employees born between 1946 and 1975. In the first week of April 2015, we sent an e-mail to these employees containing the link to a web-based survey (the ROA Public Sector Survey 2015), in which detailed questions were asked on individual and job characteristics, the existence of alternative sources of income after retirement, and partner characteristics. Moreover, it included the stated preferences experiment we use to investigate workers' retirement age and labour supply until retirement under full-time and gradual retirement schemes and different sets of financial incentives. In total, we have an estimation sample of 3,611 individuals who completed the survey. ${ }^{7}$

\section{Experimental design}

The stated preference experiment makes use of vignettes in which individuals were confronted with various hypothetical pension schemes. The stated preference experiment is introduced by a short introductory text explaining the topic, after which employees were assigned to six vignettes presenting pension scheme scenarios (involving either gradual or full retirement), including different financial incentives and containing a set of retirement

\footnotetext{
${ }^{6}$ Van Soest et al. (2007) and Kantarci and Van Soest (2013) used highly stylized regimes that are not related to actual pension schemes in the Netherlands and did not allow for different durations of gradual retirement in their scenarios.

${ }^{7}$ A further 1,643 individuals were already retired and answered a shortened version of the questionnaire that did not contain the stated preferences experiment. We also excluded 1,867 individuals who were 63 or older as it is quite likely that they have already chosen their preferred retirement path.
} 
ages and related replacement rates (in percentage of their current net income). For each scenario, respondents were asked which retirement age and associated replacement rate they prefer, making it possible to quantify how changes in financial incentives affect the gradual and full-time retirement age. Figure A1 in the Appendix shows the introductory text and two examples of the vignettes.

We designed in total ten different pension schemes scenarios with different retirement ages and replacement rate combinations. Each respondent had to respond to two baseline scenarios: one that allows workers to retire only full-time, and another one that allows workers to retire gradually. The replacement rates in both baseline scenarios closely match those applied to an average public sector employee in the Netherlands at the time of the survey with actuarially fair accruals of $5 \%$, and a $90 \%$ replacement rate upon retirement at the age of 68 for regular retirement, and at the age of 70 for gradual retirement. ${ }^{8,9}$ The other eight scenarios differ from one another in terms of the incentives for continued employment provided by the retirement scheme. We implement a price of leisure type of incentive (accruals of 7.5 or $10 \%$ for an additional year of employment), and a pension income type of incentive (decreasing pension income at all ages with 5 or $10 \%$ ). Four of these pension scheme scenarios allow workers to choose their preferred age of full-time retirement, while

\footnotetext{
${ }^{8}$ The Dutch pension system consists of three pillars. The first consists of a flat-rate public scheme (AOW) to which all residents are entitled, regardless of whether they are employee, self-employed or never participated in the labor market. The AOW provides Dutch residents with a pension benefit that guarantees $70 \%$ of the net minimum wage for a single household and 50\% for each partner in a couple (either married or officially living together). For decades, the eligibility age for the AOW was 65 . Due to a recent reform, however, the eligibility age for the large majority of the employees in our dataset will be 67. It is, however, very likely that this age will increase in the near future as the eligibility age for the AOW is now linked to the life expectancy in the Netherlands. A small but increasing percentage of Dutch employees currently remains at work after the eligibility for the state pension, on a temporary as well as a part-time basis. The second pillar consists of supplementary earnings-related pensions. This is a defined-benefit type of pension for employees organized at the sector or firm level. This pension can also be used to retire early, before the eligibility age for the state pension. Although compensation for inflation is the default for supplementary earnings-related pensions, it has not been given in the last few years, due to the rising ratio between liabilities and assets of almost all pension funds. The third pillar includes all voluntarily built-up savings that are in addition to the first two pillars. Due to the well-established first two pillars of the Dutch pension system, the third pillar is less developed in the Netherlands than in other countries.

${ }^{9}$ For gradual retirement in our scenarios, each additional year of gradual retirement is counted as half a year in terms of accrual rates.
} 
the other scenarios allow for gradual retirement with a number of years of part-time employment before full-time retirement. Apart from the baseline scenarios, each respondent was randomly given two regular and two gradual retirement scenarios. ${ }^{10}$

Table 1 shows the ten pension scenarios with their combinations of retirement age and replacement rate. Scenario 1 is the full-time baseline scenario. It offers a replacement rate of $90 \%$ of the net wage if the individual chooses to retire at the age of 68 . For each additional year of work, the replacement rate increases by 5\%-points. Scenarios 2 and 3 increase the price of leisure incentive. For each additional year of work, the replacement rate increases by 7.5\%-points and 10\%-points for Scenarios 2 and 3, respectively. However, in these two scenarios the replacement rate remains at the level of $90 \%$ of the net wage if the individual chooses to retire at the age of 68 . Scenarios 4 and 5 show the pension income incentive. While the two scenarios keep the increase in the replacement rate for each additional year of work at the level of 5\%-points, they change the replacement rate at each year of retirement, regardless of the age of retirement. In Scenario 4 the replacement rate is $85 \%$ for retiring at 68, while in Scenario 5 it is $80 \%$ for retiring at that age.

Scenarios 6 to 10 introduce gradual retirement. In these scenarios, individuals work $50 \%$ of their time and are retired for the other $50 \% .{ }^{11}$ The net income received when gradually retired is the sum of the part-time wage and the part-time pension and equals the pension after full-time retirement. Scenario 6 is the gradual retirement baseline scenario. It offers a replacement rate of $90 \%$ of the net wage if the individual chooses to work part-time at the age of 66 , and fully retires at the age of 70 . For each additional full-time-equivalent year of work, the replacement rate increases by $5 \%$-points. ${ }^{12}$ Scenarios 7 and 8 increase the price of leisure incentive. For each full-time-equivalent year of work, the replacement rate

\footnotetext{
10 The order in which the scenarios were presented to the respondents has also been randomized.

${ }^{11}$ This corresponds roughly with the average number of hours workers intend to retire part-time, as reported in the ROA Public Sector Survey 2014.

12 This means an increase in income of $2.5 \%$-points for each additional year of gradual retirement.
} 
increases by $7.5 \%$-points and $10 \%$-points in Scenarios 7 and 8 , respectively. ${ }^{13}$ The replacement rate is $90 \%$ of the net wage if the individual chooses to work part-time at the age of 66, and fully retires at the age of 70 . Scenarios 9 and 10 keep the increase in replacement rate for each additional year of full-time-equivalent work at the level of 5\%-points, but decrease the replacement rate regardless the age of retirement. In Scenario 9 the replacement rate is $85 \%$ (80\% in Scenario 10) when an individual gradually retires at the age of 66 , and fully retires at age 70 .

Finally, after the stated preferences experiment, respondents were asked to rank their choices on (part-time or full-time) retirement ages and replacement rates in the various scenarios from the most preferred (coded 6) to the least preferred one (coded 1).

\section{Descriptive statistics}

Table A1 in the Appendix shows summary statistics of respondents' main background characteristics. The table shows that the majority of the respondents in our analysis are male, highly educated employees with an average age of 56. The proportion of highly educated public sector workers in our sample is consistent with that in other datasets, such as the Dutch Labour Supply Panel. To check the randomization of the scenarios in the stated preferences experiment, Table A2 in the Appendix reports the summary statistics for all 10 retirement scenarios. The table shows that there are no statistically significant differences in background characteristics across the different scenarios.

\footnotetext{
${ }^{13}$ This implies an increase in income of $3.75 \%$-points and 5\%-points, for each additional year of gradual retirement, respectively.
} 


\section{Empirical approach}

We estimate OLS models in which we regress the preferred age of retirement and the fulltime-equivalent age of retirement (measuring total labour supply at the end of a worker's career) on the characteristics of the pension schemes in the stated preferences experiment. ${ }^{14,15}$ Because part-time retirement in our scenarios involves that individuals work $50 \%$ of their time and for the other $50 \%$ are retired, the full-time equivalent age of retirement increases with only 6 months with every additional year that individuals retire part-time. In case of a full-time pension scheme, an increase in the chosen age of retirement equals the increase in the full-time-equivalent age of retirement.

The main explanatory variable is the dummy variable that takes the value 1 if the retirement scenario includes gradual retirement (Scenarios 6-9) and 0 otherwise. We furthermore include two variables that measure the price of leisure and pension income incentives. We measure the price of leisure incentive by a variable that takes the value 0 for Scenarios 1, 4, 5, 6, 9 and 10 (5\% accruals), the value 1 for Scenarios 2 and $7(7.5 \%$ accruals), and the value 2 for Scenarios 3 or 8 (10\% accruals). Thus, a one point increase on this scale represents the effect of a 2.5 percentage point's increase in the price of leisure. We measure the pension income incentive by a variable that takes the value 0 for Scenarios 1,2 , 3, 6, 7, and 8 (90\% replacement rate), the value 1 for Scenarios 4 and 9 (85\% replacement rate), and the value 2 for Scenarios 5 and 10 (80\% replacement rate). Therefore, a one point increase on this scale represents a 5\%-points decrease in the pension income. Furthermore, we include dummy variables in our models that control for the randomisation order of the scenarios.

\footnotetext{
${ }^{14}$ The characteristics of the pension schemes include dummy variables indicating whether the scenario includes gradual retirement, which financial incentives are given by the pension system, and which randomisation order of the scenarios applied.

${ }^{15}$ Because each individual in the dataset reported a retirement age under six different retirement scenarios, we use a clustered sandwich estimator to allow for intragroup correlation on the individual level (Rogers 1993: Wooldridge 2002).
} 


\section{Gradual retirement, retirement age, and labour supply}

Main analysis

Figure 1 shows the distribution of retirement choices across the different retirement scenarios. The figure clearly shows that gradual retirement scenarios shift the retirement age upwards. While the retirement age that is most often chosen in the full-time retirement scenarios ranges between ages 65 and 66, respondents most often choose the age of 67 for full retirement in gradual retirement scenarios. Ages 65 and 66 correspond to the past social norm in the Netherlands to retire at the old eligibility age of 65 for the statutory old age pension, while age 67 corresponds to the highest eligibility age as of 2021 . The figure furthermore shows that the expected retirement age is responsive to financial incentives, and that at each level of financial incentives, the expected retirement age is slightly higher in gradual retirement scenarios than in full-time retirement scenarios. Most strikingly, the gradual retirement option in combination with strong financial incentives to postpone retirement induces about $17.5 \%$ of the workers in our sample to continue working until age 70.

Table 2 provides more evidence by summarising the average retirement age and the full-time-equivalent age of retirement under each retirement scenario. The table shows that under the full-time retirement scenarios, the average retirement age (and full-time-equivalent age of retirement) in the baseline scenario is 64.97 years. The average retirement age increases to 65.84 when the price of leisure incentive increases from 5\%-points to $7.5 \%$ points (Scenario 2), and additionally slightly increases to 66.05 when the price of leisure incentive goes from $7.5 \%$-points to $10 \%$-points (Scenario 3). A 5\%-points decrease in pension income (Scenario 4) increases the age of retirement to 65.40. A further decrease in pension income by 5\%-points increases the average age of retirement to almost 66 years (Scenario 5). 
The table further confirms that average expected retirement ages are higher under gradual retirement scenarios than under full-time retirement scenarios with the same price of leisure or pension income incentives. However, the results change considerably when we look at the average full-time-equivalent retirement age. In the baseline scenario for gradual retirement (Scenario 6), the average retirement age is 65.95 which is almost one year later than in the full-time baseline scenario (Scenario 1). The average full-time-equivalent retirement age is, however, only 64.77, which is less than the average full-time retirement age in baseline scenario 1 . When the price of leisure incentive increases to $7.5 \%$ and $10 \%$ in the gradual retirement scenarios (Scenarios 7 and 8), respectively, the average retirement age increases to 66.65 and 67.18 , while the average full-time-equivalent retirement age increases only to 65.36 and 65.79 , respectively. This implies that the average full-time-equivalent retirement age in these two scenarios is lower than the average full-time-equivalent retirement age in the full time retirement scenarios 2 and 3. Similarly, decreasing the pension income to $85 \%$ and $80 \%$ in the gradual retirement scenarios 9 and 10 increases the average retirement age to 66.34 and 66.68 , and increases the average full-time-equivalent retirement age to 65.10 and 65.59 , respectively. The average full-time-equivalent age in these two scenarios is again lower than in the scenarios 4 and 5 . The results presented in Table 2 therefore suggest that, although gradual retirement increases the retirement age, its impact on workers' labour supply is negative. Moreover, the table shows that financial incentives to postpone retirement, irrespective whether they generate price of leisure or income shocks, increase both the expected retirement age and labour supply.

Table 3 shows the OLS estimations of the effect of gradual retirement on the expected retirement age (Columns 1-3) and the full-time-equivalent retirement age (Columns 4-6). Columns 1 and 4 show raw estimates which include only a dummy variable indicating whether the scenarios include gradual retirement. Columns 2 and 5 control for financial 
incentives (i.e., price of leisure and pension income), and Columns 3 and 6 include an interaction between gradual retirement and financial incentives to investigate the extent to which the impact of gradual retirement schemes differs with the financial incentives provided by the pension system to continue working. The table shows that in gradual retirement systems workers expect to retire about one year later than in full-time retirement systems. When we consider the full-time equivalent retirement age, however, workers retire on average 3.4 months earlier under gradual retirement schemes. The replacement of full-time retirement schemes with gradual retirement schemes will therefore have negative consequences on workers' overall labour supply, as the positive effect of gradual retirement on labour supply, as consequence of the postponement of full-time retirement, is outweighed by the reduction in labour supply due to the drop in weekly working hours in the years before full-time retirement.

Table 3 further shows that a $2.5 \%$-points increase in accruals postpones the expected retirement age by about 7.2 months, and that a 5\%-points decrease in pension income increases the retirement age with 5.6 months. More importantly, we find no significant interaction effect between the financial incentives and our gradual retirement indicator on the expected retirement age. We do find, however, a small statistically significant negative interaction effect on the full-time-equivalent age of retirement, suggesting that labour supply under gradual retirement scenarios is slightly less responsive to changes in financial incentives.

Figures $2 \mathrm{a}$ and $2 \mathrm{~b}$ show the marginal effects (relative to the full-time base Scenario 1 ) for the different retirement scenarios on the probability to retire late (at ages 67 or older), at ages 65 and 66, or early (at age 62-64). The marginal effects are calculated based on the coefficient estimates of the multinomial logit model presented in Table A4 in the Appendix, and allow us to check for nonlinearities in the impact of gradual retirement on retirement 
expectations. ${ }^{16}$ The figures show results that are largely consistent with the OLS estimates in Table 3. Gradual retirement substantially reduces the likelihood that workers wish to retire early (17\%-points less likely to retire than in the base scenario) or at ages 65 and 66 (7\%points less likely to retire). ${ }^{17}$ The figures furthermore show that especially strong accrual rates in combination with gradual retirement stimulate workers more to retire late (at age 67 or later) compared to the base scenario. Recall, however, that both interaction effects between the financial incentives and our gradual retirement indicator on the average expected retirement age in Table 3 were not statistically significant.

\section{Ranking preferences for gradual and full-time retirement}

From a theoretical perspective, we would expect that gradual-retirement schemes can contribute to improve life time utility as they introduce the possibility to avoid a shock due to the abrupt transition from full-time work to full-time retirement. Gradual retirement may further reduce the burden of work, and thereby reduce work-related stress and increase employee morale until full retirement (Reday-Mulvey and Delsen 1996; Reday-Mulvey 2000).

To measure respondents' preferences for gradual retirement, we asked respondents to rank the choices they made in each of the six vignette scenarios. The respondents could rank their choices from most preferred (coded 6) to least preferred (coded 1). Column 1 of Table 4 shows the average ranking of each retirement scenario. The table shows that the baseline fulltime retirement scenario, which also includes the most generous financial incentives, is the most preferred one (rank is 5.13), while the baseline gradual retirement scenario is less often preferred (rank is 4.39). When we compare the ranking of the other scenarios, it becomes clear that none of the gradual retirement scenarios is on average preferred to the full-time

\footnotetext{
${ }^{16}$ See also Van Soest et al. (2007) and Kantarci and Van Soest (2013).

17 This result is robust to different definitions of early and late retirement.
} 
scenarios with equivalent financial incentives. Column 2 of Table 4 further shows that $57 \%$ of all workers chose the baseline full-time retirement scenario as their most preferred scenario, while only $26 \%$ chose the baseline gradual retirement scenario as their most preferred scenario.

Table 5 reports OLS-estimates on how the various attributes of the retirement scenarios relate to the rank of the scenarios. ${ }^{18}$ The table confirms that workers still prefer fulltime retirement. Scenarios with higher prices for leisure or stronger pension income incentives to postpone retirement are, as could be expected, ranked lower. The analysis including the interactions between gradual retirement and the two financial incentives finally shows that workers especially have distaste for the scenario including a combination of gradual retirement and price of leisure incentives. This could be due to the fact that in the gradual retirement regime, workers already pay a higher price (in terms of lower replacement rates) for more leisure time.

The results of our ranking analysis are thus not in line with our expectation that the introduction of gradual retirement opportunities would lead to substantially different retirement patterns (Reday-Mulvey and Delsen 1996; Reday-Mulvey 2000). However, our results are consistent with other studies which showed that many workers are more likely to choose full-retirement over partial retirement (Van Soest et al. 2006; and Kantarci and Van Soest 2013).

\section{Heterogeneity in preferences}

The above findings are likely to hide underlying heterogeneity in the way gradual retirement affects the retirement age and labour supply across groups of workers, as well as preferences for gradual retirement. Previous evidence by De Grip et al. (2013) showed that an announced

\footnotetext{
${ }^{18}$ Table A5 reports marginal effects of a multinomial logit model on the ranking of the six scenarios. The table shows that there are no strong non-linearities in the impact of gradual retirement on the ranking of the different scenarios.
} 
increase in the eligibility age for the statutory old age pension in the Netherlands leads to substantially different treatment effects for different groups of workers. We here analyse the extent to which the introduction of gradual retirement opportunities affects differently the retirement age, the full-time equivalent retirement age, and the ranking of the scenarios of different groups of workers. We look at the following personal and job characteristics: gender, age, education level, wage, marital status, whether workers have a partner with own income, whether the partner works, the number of sick days in the past year, and selfassessed life expectancy. ${ }^{19}$

Table 6 shows the OLS regressions of the heterogeneous treatment effects on workers' retirement age (Column 1), the full-time-equivalent retirement age (Column 2), and the ranking of the scenarios (Column 3). The interaction term between each personal characteristic and the gradual retirement dummy indicates whether different types of workers react differently to the gradual retirement option. The table shows that highly-educated, married, workers who have partners with own income, and those who have many sick days or lower self-assessed life expectancy choose to retire earlier. ${ }^{20}$ There are, however, small heterogeneous effects in the interaction between personal and job characteristics and gradual retirement. We find that highly educated workers tend to retire earlier when they have the option to gradually retire, while workers who are married will retire somewhat later. ${ }^{21}$ Table 6 further shows that workers with a high wage rank gradual retirement significantly higher, which is consistent with abundant evidence suggesting that the elasticity of weekly hours of work with respect to the wage rate is negative (Camerer 1997; Chou 2002; Fehr and Götte 2007). Workers with a higher life expectancy, rank the gradual retirement option significantly

\footnotetext{
${ }^{19}$ Subjective survival probabilities are measured by the following survey question: How large do you think is the chance that you will attain (at least) the age of 80, where 0 means 0\% change and 100 means 100\% change?

${ }^{20}$ Highly educated workers may tend to retire early because they are more likely to have accumulated sufficient pension wealth. Our data, however, do not allow us to control for workers' wealth.

${ }^{21}$ As a robustness check, we also estimated a multinomial logit model to account for non-linearity and found similar results.
} 
lower, most likely because their longer life expectancy prolongs the period in which they receive pension benefits.

We also analyse in more detail how the content of a worker's job in terms of routine and non-routine job tasks affects the impact of gradual retirement. The extent to which employees perform routine or non-routine tasks is measured by the following survey question:

How often do you spend time on the following tasks in your job? You can give your answer on a scale from 0 until 10, where 0 means 'never' and 10 means 'always':

1) Short repetitive tasks (fixed procedures etc.)

2) Supervision of other employees

3) Solving problems for which it takes at least 30 minutes to come to an adequate solution.

We take item 1 as an indicator for routine tasks, while our indicator of the extent to which employees perform non-routine tasks is based on the arithmetic average of items 2 and 3 .

Table 7 shows the heterogeneity analyses by job tasks. The table shows that workers who perform more non-routine tasks in their job are more likely to retire earlier, but that the opportunity to retire more gradually induces them to stay longer in the labour market which increases their net labour supply. ${ }^{22}$ This is consistent with the evidence by De Grip et al. (2013) that employees who have psychologically demanding tasks will retire early in a fulltime retirement system. Gradual retirement may subsequently help them to better cope with the heavy mental work demands in their job, allowing them to maintain their job to a later age. We do also observe, however, that these workers do not rank the gradual retirement

\footnotetext{
${ }^{22}$ These results are robust to the inclusion of the education dummies and their interactions with the gradual retirement option as reported in Table 6.
} 
option higher, which might be because workers with cognitive demanding tasks are also often more constrained to work part-time.

\section{Conclusion}

In this paper, we use data from a stated preferences experiment to study the extent to which gradual retirement affects workers' retirement age and labour supply. Existing exploratory evidence in the literature suggests that gradual retirement may not lead to a net increase in total labour supply of older workers (e.g., Gielen 2009; Machado and Portela 2012). However, these studies focused on actual retirement decisions and therefore do not identify all retirement options which were available to older workers, because the options that are not chosen cannot be observed, or because it is not even clear which options could have been chosen by workers (Kantarci and Van Soest 2008, 2013). Stated preferences solve this problem by capturing a broader array of preference-driven behaviours, and can therefore be used to estimate the causal relation between gradual retirement and a worker's age of retirement and labour supply. Concerns may arise about the external validity of retirement options in stated preference studies, especially if these retirement options are not yet existent in reality (Kantarci and Van Soest 2013). ${ }^{23}$ However, the literature shows that stated preference estimates and the estimates based on actual behaviour data are usually quite close (Louviere et al. 2000).

We find that gradual retirement schemes, compared to full retirement schemes, stimulates worker to retire approximately one year later. Total labour supply, however, significantly decreases in gradual retirement systems, as the positive effect of postponing retirement on labour supply is cancelled out by the reduction of working hours before full retirement. We furthermore show that financial incentives to postpone retirement (changes in

\footnotetext{
${ }^{23}$ Another limitation of our study is that we focus on public sector employees. The sectors covered are, however, large and include $13 \%$ of the total Dutch labour force.
} 
the accrual rate in the pension scheme and reductions in pension income) significantly increase the expected retirement age. However, the impact of financial incentives on workers' retirement expectations is similar across gradual and full retirement options.

From a policy perspective, the introduction of gradual retirement options could be welfare enhancing, as those who do prefer such option would choose it, and those who don't would not choose to retire gradually. However, our ranking analysis of the different pension scheme scenarios shows that gradual retirement is not a preferred option among workers as the large majority still prefers full retirement. This holds particularly for workers with lower wages or high life expectancy. Our results also suggest that changing current retirement schemes into gradual retirement schemes would not contribute to a further increase in the labour supply of older generations. There is, however, some heterogeneity across workers as those with non-routine job tasks may be inclined to postpone their retirement when they have the possibility to gradually retire. It is therefore possible that sectors that employ a large share of workers with non-routine job tasks can increase their labour supply if they shift from a full-time retirement scheme to a gradual retirement scheme. 


\section{References}

Börsch-Supan, A.H. (2012) Entitlement reforms in Europe: policy mixes in the current pension reform process. No. w18009. National Bureau of Economic Research.

Camerer, Colin, Linda Babcock, George Loewenstein \& Richard Thaler (1997), Labor Supply of New York City Cabdrivers: One Day at a Time, Quarterly Journal of Economics; 112(2), 407-41.

Chou, Yuan K. (2002), Testing alternative models of labor supply: evidence from taxi drivers in Singapore, Singapore Economic Review, 47, 17-47

De Grip, A. Lindeboom, M., \& Montizaan, R. (2012). Shattered dreams: The effects of changing the pension system late in the game. The Economic Journal, 122(559), 1-25.

De Grip, A., Fouarge, D., \& Montizaan, R. (2013). How sensitive are individual retirement expectations to raising the retirement age?. De Economist, 161(3), 225-251.

Duval, R. (2005). The retirement effect of old-age pension and early retirement schemes in OECD countries, in Economic Policy reforms 2005: Going for Growth, OECD publishing.

Fehr, E., \& L. Götte (2007). Do workers work more if wages are high? Evidence from a randomized field experiment. American Economic Review, 97(1): 298-317.

Gielen, A. C. (2009). Working hours flexibility and older workers' labour supply. Oxford Economic Papers, 61 (2), 240-274

Gruber, J., \& Wise, D. (1998). Social security and retirement: An international comparison. American Economic Review, 88(2), 158-163.

Gustman, A. L., \& Steinmeier, T. L. (2004). Minimum hours constraints, job requirements and retirement (No. w10876). National Bureau of Economic Research.

Hutchens, R. (2010). Worker characteristics, job characteristics, and opportunities for phased retirement. Labour Economics, 17(6), 1010-1021. 
Kangas, O., Lundberg, U., \& Ploug, N. (2010). Three routes to pension reform: Politics and institutions in reforming pensions in Denmark, Finland and Sweden. Social Policy \& Administration, 44(3), 265-284.

Kantarc1, T., \& van Soest, A. (2013). Stated Preference Analysis of Full and Gradual retirement in the United States. Cesr-Schaeffer Working Paper Series. Paper No: 2013-011

Kantarci, T., \& Van Soest, A. (2008). Gradual retirement: preferences and limitations. De Economist, 156(2), 113-144.

Krause, N., Lynch, J., Kaplan, G. A., Cohen, R. D., Goldberg, D. E., \& Salonen, J. T. (1997). Predictors of disability retirement. Scandinavian journal of work, environment \& health, 23(6), 403-413.

Latulippe, D., \& Turner, J. (1997). Gradual retirement in the OECD countries. International Labour Review, 136(4), 581.

Louviere, J. J., Hensher, D. A., Swait, J. D. (2000). Stated choice methods: Analysis and applications. Cambridge University Press.

Machado, C. S., \& Portela, M. (2012). Hours of Work and Retirement Behavior. IZA DP No. 6270.

Mastrobuoni, G. (2009). Labor supply effects of the recent social security benefit cuts: Empirical estimates using cohort discontinuities. Journal of Public Economics, 93(11), 1224-1233.

McNair, S. (2006). How different is the older labour market? Attitudes to work and retirement among older people in Britain. Social Policy and Society, 5(04), 485-494.

OECD (2006). Live longer, work longer: A synthesis report (Ageing and employment policies), OECD publishing. 
Reday-Mulvey, G. (2000). Gradual retirement in Europe. Journal of Aging and Social Policy, 11(2-3), 49-60.

Reday-Mulvey, G. \& L. Delsen (1996). Gradual retirement in the OECD countries: A summary of the main results. Geneva Papers on Risk and Insurance Issues and Practice, 21(81), 502-523.

Rogers, W.H. (1993). Regression standard errors in clustered samples. Stata Technical Bulletin, Vol. 13, 19-23.

Siegrist, J. (1996). Adverse health effects of eigh-effort/low-reward Conditions. Journal of Occupational Health Psychology, 1(1), 27.

Staubli, S., \& Zweimüller, J. (2013). Does raising the retirement age increase employment of older workers?. Journal of Public Economics, 108, 17-32

Van Soest, A., \& Vonkova, H. (2014). How sensitive are retirement decisions to financial incentives? A stated preference analysis. Journal of Applied Econometrics, 29(2), 246-264.

Van Soest, A., Kapteyn, A., \& Zissimopoulos, J. (2007). Using Stated Preferences Data to Analyze Preferences for Full and gradual retirement. IZA DP No. 2785.

Wadensjö, E. (2006). Part-time pensions and part-time work in Sweden. European Papers on the New Welfare, No. 6, 29-45.

Wahrendorf, M., Dragano, N., \& Siegrist, J. (2013). Social position, work stress, and retirement intentions: a study with older employees from 11 European countries. European Sociological Review, 29 (4): 792-802.

Warren, D.A. (2015). Pathways to retirement in Australia: Evidence from the HILDA survey. Work, Aging and Retirement . http://dx.doi.org/10.1093/workar-/wau013

Wooldridge, J.M. (2002). Econometric analysis of cross section and panel data, Cambridge, MA: MIT Press. 
Figure 1: The distribution of retirement age choices
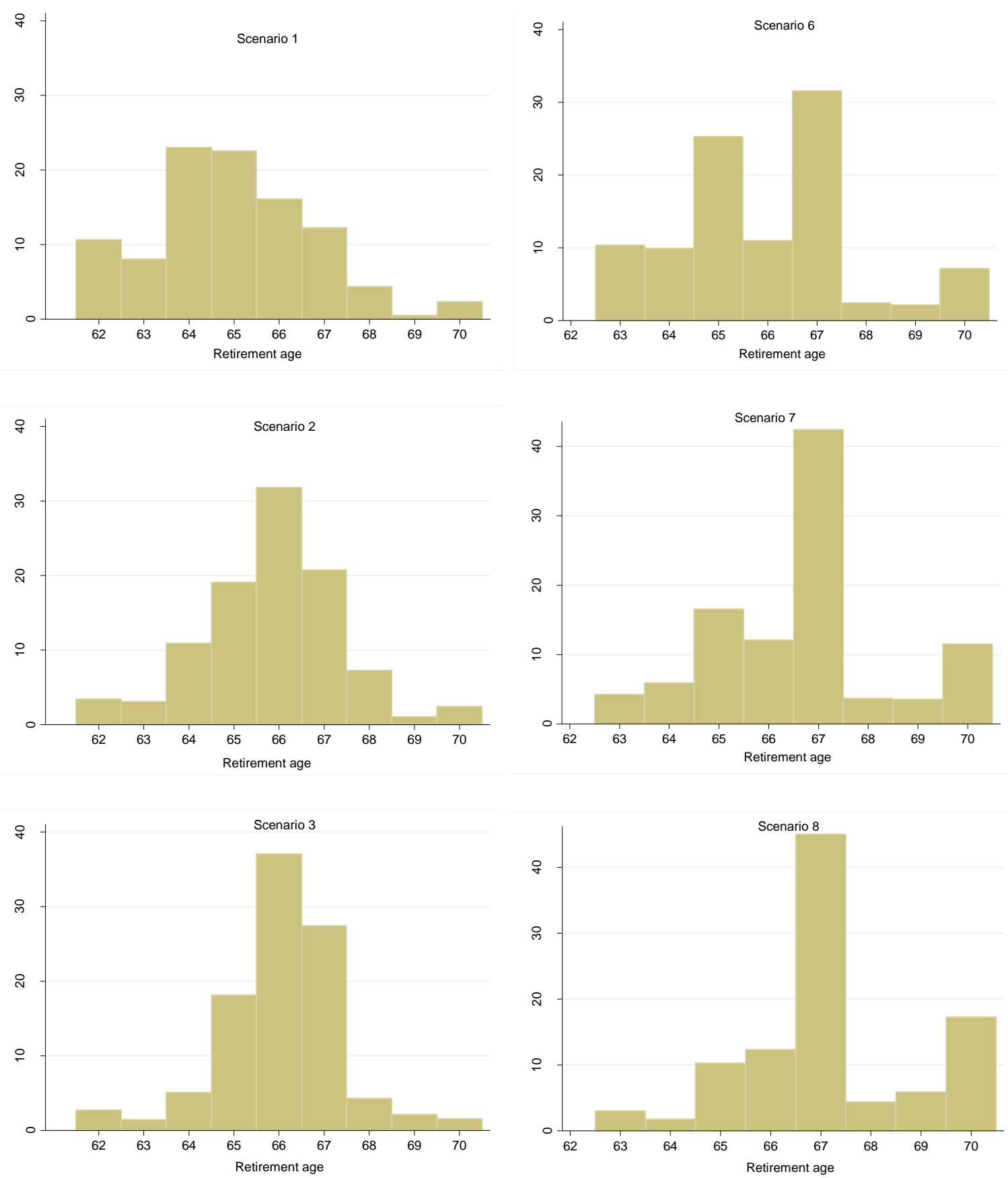

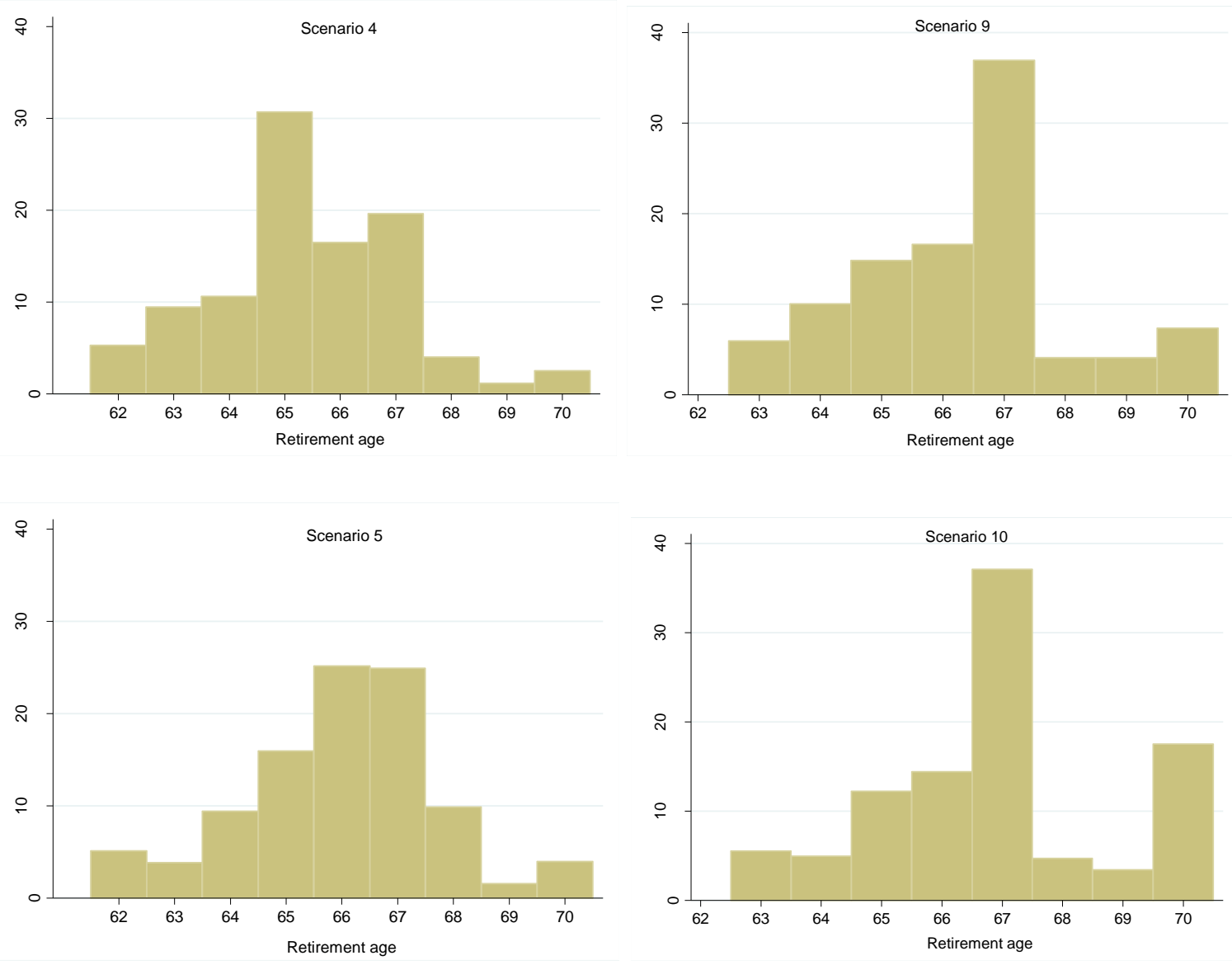
Figure 2a: Differences in marginal effects of a multinomial logit on early, middle and late retirement: shocks in accrual rates and gradual retirement (marginal effects relative to the full-time base scenario)

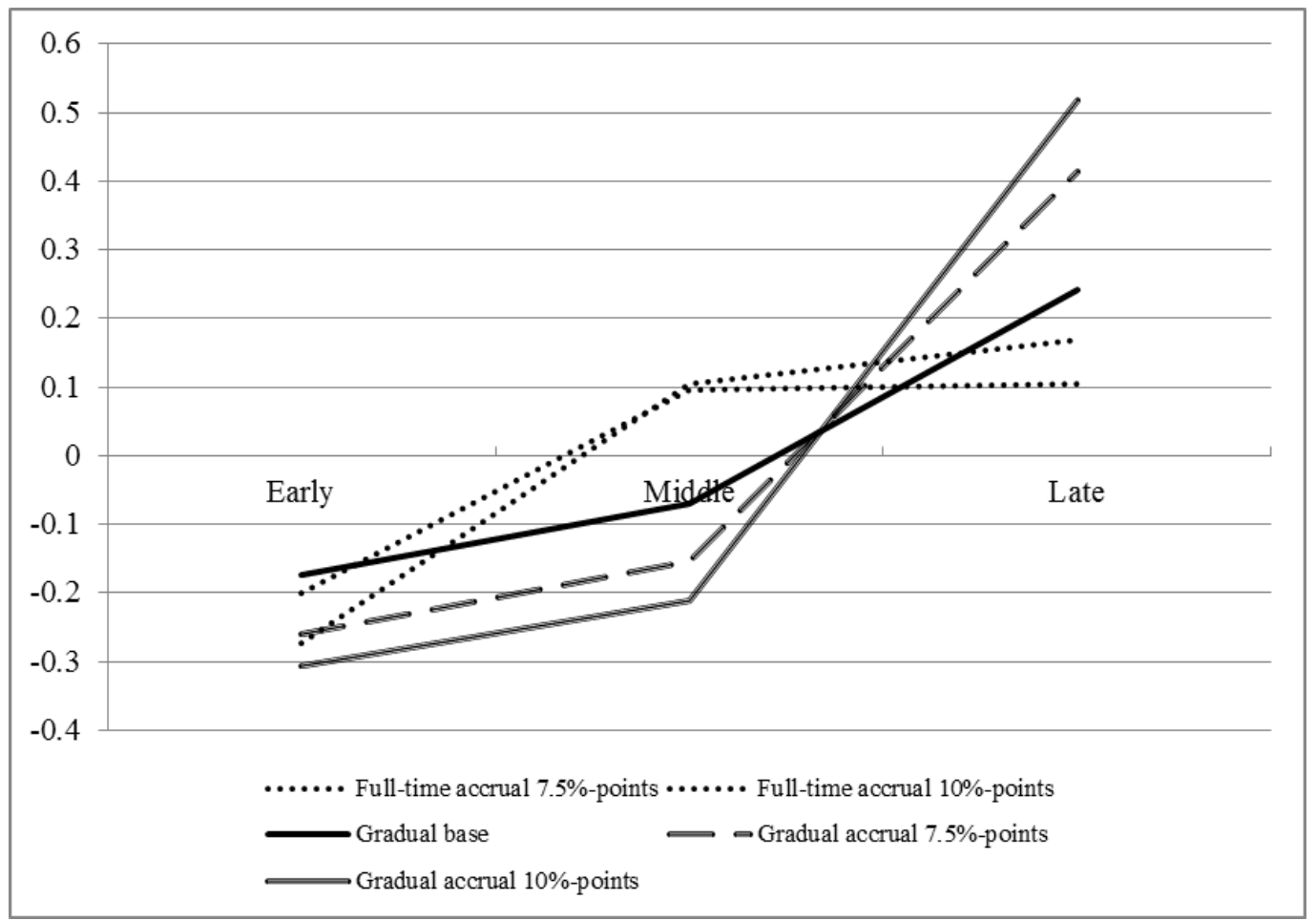

Figure 2b: Differences in marginal effects of a multinomial logit on early, middle and late retirement: income shocks and gradual retirement (marginal effects relative to the full-time base scenario)

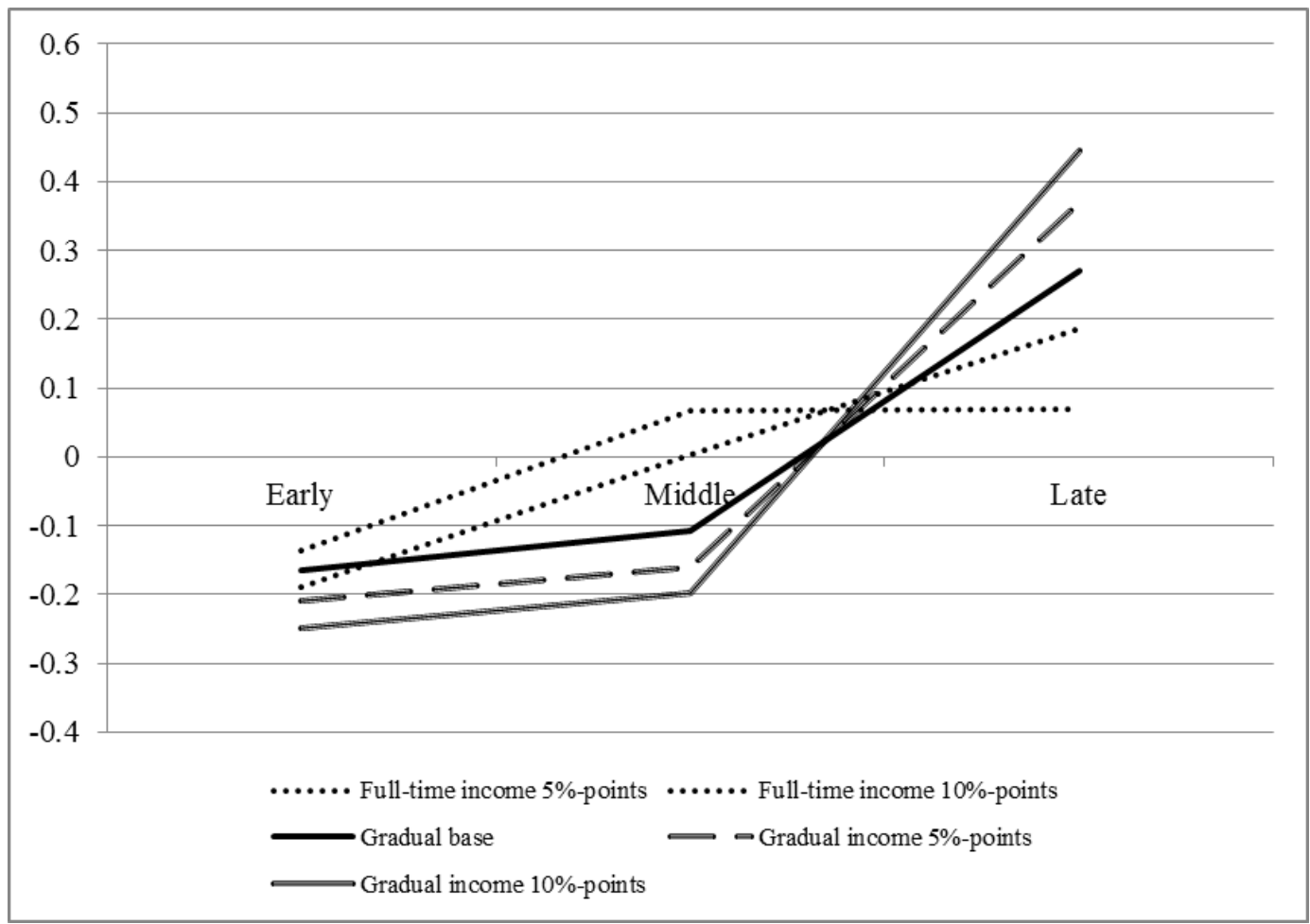


Table 1: Retirement scenarios

\begin{tabular}{|c|c|c|c|c|c|c|}
\hline & Retirement age & 1 & 2 & 3 & 4 & 5 \\
\hline & & Baseline & \multicolumn{2}{|c|}{ Price of leisure incentive } & \multicolumn{2}{|c|}{ Pension wealth incentive } \\
\hline \multirow[t]{12}{*}{$\begin{array}{l}\text { Regular } \\
\text { retirement }\end{array}$} & & $\begin{array}{l}\text { accruals: } 5 \% \text {; } \\
\text { replacement } \\
\text { rate: } 90 \% \text { at } \\
68\end{array}$ & $\begin{array}{l}\text { accruals } 7.5 \% \text {; } \\
\text { replacement } \\
\text { rate: } 90 \% \text { at } \\
68\end{array}$ & $\begin{array}{l}\text { accruals } \\
10 \% ; \\
\text { replacement } \\
\text { rate: } 90 \% \text { at } \\
68\end{array}$ & $\begin{array}{l}\text { accruals } 5 \% \\
\text { replacement } \\
\text { rate: } 85 \% \text { at } \\
68\end{array}$ & $\begin{array}{l}\text { accruals 5\%; } \\
\text { replacement } \\
\text { rate: } 80 \% \text { at } \\
68\end{array}$ \\
\hline & 62 & 60 & 45 & 30 & 55 & 50 \\
\hline & 63 & 65 & 52.5 & 40 & 60 & 55 \\
\hline & 64 & 70 & 60 & 50 & 65 & 60 \\
\hline & 65 & 75 & 67.5 & 60 & 70 & 65 \\
\hline & 66 & 80 & 75 & 70 & 75 & 70 \\
\hline & 67 & 85 & 82.5 & 80 & 80 & 75 \\
\hline & 68 & 90 & 90 & 90 & 85 & 80 \\
\hline & 69 & 95 & 97.5 & 100 & 90 & 85 \\
\hline & 70 & 100 & 105 & 110 & 95 & 90 \\
\hline & & 6 & 7 & 8 & 9 & 10 \\
\hline & & Baseline & \multicolumn{2}{|c|}{ Price of leisure incentive } & \multicolumn{2}{|c|}{ Pension wealth incentive } \\
\hline $\begin{array}{l}\text { Gradual } \\
\text { retirement }\end{array}$ & & $\begin{array}{l}\text { accruals: } 5 \% \text {; } \\
\text { replacement } \\
\text { rate: } 90 \% \text { at } \\
68\end{array}$ & $\begin{array}{l}\text { accruals } 7.5 \% \text {; } \\
\text { replacement } \\
\text { rate: } 90 \% \text { at } \\
68\end{array}$ & $\begin{array}{l}\text { accruals } \\
10 \% ; \\
\text { replacement } \\
\text { rate: } 90 \% \text { at } \\
68\end{array}$ & $\begin{array}{l}\text { accruals } 5 \% \text {; } \\
\text { replacement } \\
\text { rate: } 85 \% \text { at } \\
68\end{array}$ & $\begin{array}{l}\text { accruals 5\%; } \\
\text { replacement } \\
\text { rate: } 80 \% \text { at } \\
68\end{array}$ \\
\hline & $62-63$ & 62.5 & 48.75 & 35 & 57.2 & 52.5 \\
\hline & $62-64$ & 65 & 52.5 & 40 & 60 & 55 \\
\hline & $63-64$ & 67.5 & 56.25 & 45 & 62.5 & 57.5 \\
\hline & $63-65$ & 70 & 60 & 50 & 65 & 60 \\
\hline & $62-67$ & 72.5 & 63.75 & 55 & 67.5 & 62.5 \\
\hline & $64-65$ & 72.5 & 63.75 & 55 & 67.5 & 62.5 \\
\hline & $63-67$ & 75 & 67.5 & 60 & 70 & 65 \\
\hline & $64-66$ & 75 & 67.5 & 60 & 70 & 65 \\
\hline & $66-67$ & 77.5 & 71.25 & 65 & 72.5 & 67.5 \\
\hline & $65-66$ & 77.5 & 71.25 & 65 & 72.5 & 67.5 \\
\hline & $62-70$ & 80 & 75 & 70 & 75 & 70 \\
\hline & $65-67$ & 80 & 75 & 70 & 75 & 70 \\
\hline & $63-70$ & 82.5 & 78.75 & 75 & 77.5 & 72.5 \\
\hline & $66-67$ & 82.5 & 78.75 & 75 & 77.5 & 72.5 \\
\hline & $65-69$ & 85 & 82.5 & 80 & 80 & 75 \\
\hline & $66-68$ & 85 & 82.5 & 80 & 80 & 75 \\
\hline & $66-69$ & 87.5 & 86.25 & 85 & 82.5 & 77.5 \\
\hline & $67-68$ & 87.5 & 86.25 & 85 & 82.5 & 77.5 \\
\hline & $66-70$ & 90 & 90 & 90 & 85 & 80 \\
\hline & $67-70$ & 92.5 & 93.75 & 95 & 87.5 & 82.5 \\
\hline & $68-70$ & 95 & 97.5 & 100 & 90 & 85 \\
\hline & $69-70$ & 97.5 & 101.25 & 105 & 92.5 & 87.5 \\
\hline
\end{tabular}

* Under gradual retirement scenarios, the first age is the age of starting work on part-time (gradual) basis, and the second age is the age of full retirement. 
Table 2: Retirement scenarios, retirement age, and full-time-equivalent age of retirement

\begin{tabular}{|c|c|c|c|c|c|}
\hline \multirow[t]{2}{*}{ Scenario } & 1 & \multicolumn{2}{|l|}{2} & \multicolumn{2}{|r|}{5} \\
\hline & Baseline & \multicolumn{2}{|c|}{ Price of leisure incentive } & \multicolumn{2}{|c|}{ Pension wealth incentive } \\
\hline Regular retirement & $\begin{array}{l}\text { accruals: } \\
5 \% \text {; } \\
\text { replacement } \\
\text { rate: } 90 \% \text { at } \\
68\end{array}$ & $\begin{array}{l}\text { accruals } 7.5 \% \text {; } \\
\text { replacement } \\
\text { rate: } 90 \% \text { at } \\
68\end{array}$ & $\begin{array}{l}\text { accruals } \\
10 \% ; \\
\text { replacement } \\
\text { rate: } 90 \% \text { at } \\
68\end{array}$ & $\begin{array}{l}\text { accruals 5\%; } \\
\text { replacement } \\
\text { rate: } 85 \% \text { at } \\
68\end{array}$ & $\begin{array}{l}\text { accruals 5\%; } \\
\text { replacement } \\
\text { rate: } 80 \% \text { at } \\
68\end{array}$ \\
\hline \multirow[t]{2}{*}{ Retirement age } & 64.97 & 65.84 & 66.05 & 65.40 & 65.99 \\
\hline & $(1.80)$ & $(1.56)$ & $(1.36)$ & (1.72) & (1.77) \\
\hline \multirow{2}{*}{$\begin{array}{l}\text { Full-time- } \\
\text { equivalent age of } \\
\text { retirement }\end{array}$} & 64.97 & 65.84 & 66.05 & 65.40 & 65.99 \\
\hline & $(1.80)$ & $(1.56)$ & $(1.36)$ & $(1.72)$ & $(1.77)$ \\
\hline \multirow[t]{2}{*}{ Scenario } & 6 & 7 & 8 & 9 & 10 \\
\hline & Baseline & \multicolumn{2}{|c|}{ Price of leisure incentive } & \multicolumn{2}{|c|}{ Pension wealth incentive } \\
\hline Gradual retirement & $\begin{array}{l}\text { accruals: } \\
5 \% \text {; } \\
\text { replacement } \\
\text { rate: } 90 \% \text { at } \\
68\end{array}$ & $\begin{array}{l}\text { accruals } 7.5 \% \text {; } \\
\text { replacement } \\
\text { rate: } 90 \% \text { at } \\
68\end{array}$ & $\begin{array}{l}\text { accruals } \\
10 \% ; \\
\text { replacement } \\
\text { rate: } 90 \% \text { at } \\
68\end{array}$ & $\begin{array}{l}\text { accruals 5\%; } \\
\text { replacement } \\
\text { rate: } 85 \% \text { at } \\
68\end{array}$ & $\begin{array}{l}\text { accruals 5\%; } \\
\text { replacement } \\
\text { rate: } 80 \% \text { at } \\
68\end{array}$ \\
\hline \multirow[t]{2}{*}{ Retirement age } & 65.95 & 66.65 & 67.18 & 66.34 & 66.88 \\
\hline & $(1.83)$ & $(1.76)$ & $(1.73)$ & (1.75) & (1.92) \\
\hline \multirow{2}{*}{$\begin{array}{l}\text { Full-time- } \\
\text { equivalent age of } \\
\text { retirement }\end{array}$} & 64.77 & 65.36 & 65.79 & 65.10 & 65.59 \\
\hline & (1.47) & $(1.38)$ & $(1.27)$ & (1.44) & $(1.56)$ \\
\hline
\end{tabular}

In case of a full-time pension scheme, the increase in the preferred age of retirement is equal to the increase in the full-timeequivalent retirement age. Because employees who gradually retire are defined to only work $50 \%$ of a full-time job in the vignettes, an increase in the preferred part-time retirement age with one year increases the full-time equivalent retirement age with only 6 months. 
Table 3: The relationship between gradual retirement and retirement age and full-time-equivalent age of retirement

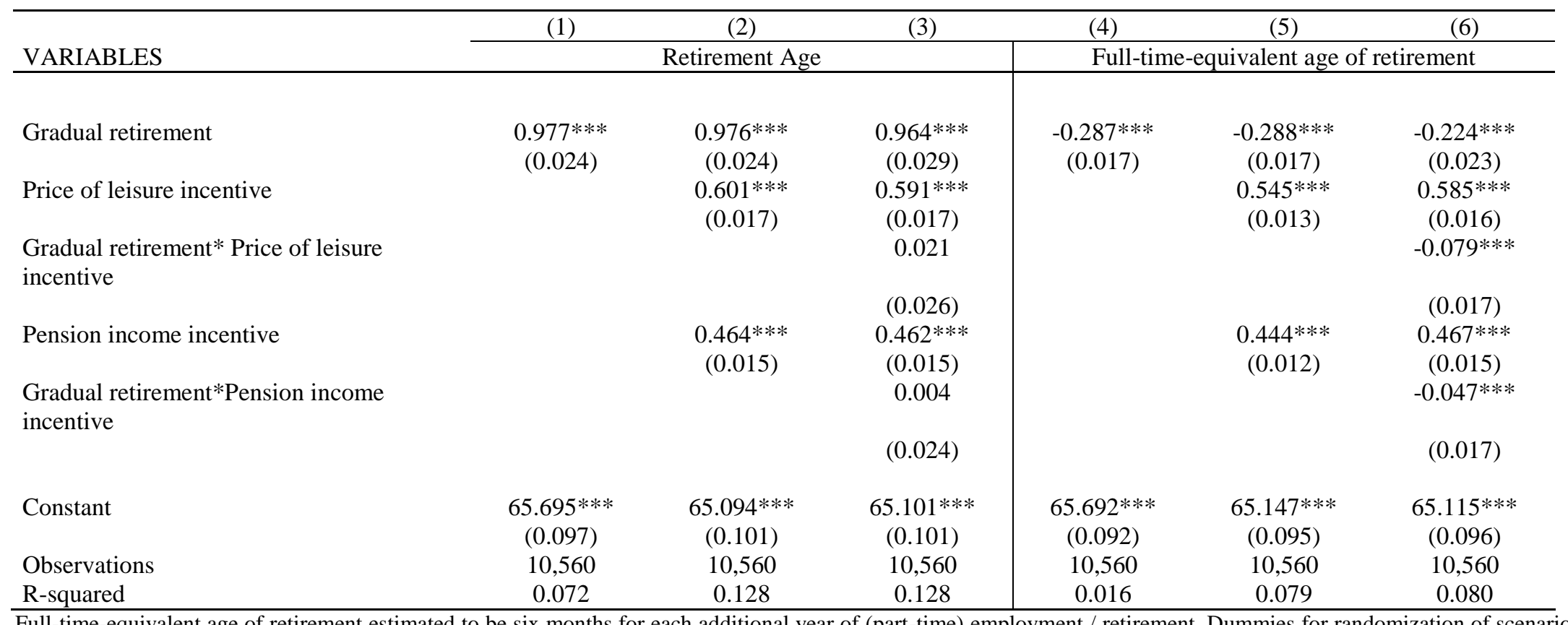

Full-time-equivalent age of retirement estimated to be six months for each additional year of (part-time) employment / retirement. Dummies for randomization of scenarios included as controls. OLS estimates including robust standard errors corrected for clustering on the individual level in parentheses $* * * \mathrm{p}<0.01, * * \mathrm{p}<0.05$, * $\mathrm{p}<0.1$ 
Table 4: Ranking of preferences for different retirement scenarios

\begin{tabular}{lcc}
\hline Retirement Scenario & $\begin{array}{c}\text { Average } \\
\text { ranking }\end{array}$ & $\begin{array}{c}\text { Percentage most } \\
\text { preferred scenario }\end{array}$ \\
\hline Scenario 1 & 5.13 & 57.4 \\
Scenario 2 & 3.83 & 5.0 \\
Scenario 3 & 2.85 & 2.2 \\
Scenario 4 & 3.80 & 2.4 \\
Scenario 5 & 2.54 & 0.9 \\
Scenario 6 & 4.39 & 26.2 \\
Scenario 7 & 3.06 & 2.6 \\
Scenario 8 & 1.95 & 1.0 \\
Scenario 9 & 3.06 & 1.3 \\
Scenario 10 & 1.85 & 1.1 \\
\hline In total, 6 scenarios were ranked by the respondents. The most \\
preferred scenario is attributed value 6, while the least preferred \\
scenario was attributed value 1. Column 1 shows the average ranking \\
of the scenarios. Column 2 shows how many workers chose the \\
different scenarios as their most preferred scenario.
\end{tabular}


Table 5: Ranking the scenarios

\begin{tabular}{lccc}
\hline VARIABLES & $(1)$ & $(2)$ & $(3)$ \\
\hline Gradual retirement & & & \\
& & & \\
Price of leisure incentive & $(0.764 * * *$ & $-0.764 * * *$ & $-0.732^{* * *}$ \\
& & $(0.043)$ & $(0.054)$ \\
Gradual retirement* Price of leisure incentive & & $-1.189 * * *$ & $-1.150^{* * *}$ \\
& & $(0.024)$ & $(0.031)$ \\
Pension income incentive & & $-0.077 * *$ \\
& & $-1.273 * * *$ & $-1.280^{* * *}$ \\
Gradual retirement*Pension income incentive & & $(0.021)$ & $(0.028)$ \\
& & & 0.015 \\
Constant & & & $(0.038)$ \\
& & $5.112 * * *$ & $5.096 * *$ \\
Observations & $3.881 * * *$ & $(0.028)$ & $(0.033)$ \\
R-squared & $(0.022)$ & 8,897 & 8,897 \\
\hline
\end{tabular}

OLS-estimated including robust standard errors corrected for clustering on the individual level in parentheses $* * *$ $\mathrm{p}<0.01, * * \mathrm{p}<0.05, * \mathrm{p}<0.1$. 
Table 6: Gradual retirement and full-time-equivalent age of retirement, heterogeneity analysis on personal characteristics

\begin{tabular}{|c|c|c|c|}
\hline VARIABLES & $\begin{array}{c}\text { (1) } \\
\text { Retirement age }\end{array}$ & $\begin{array}{c}(2) \\
\text { Fulltime } \\
\text { equivalent of } \\
\text { retirement age }\end{array}$ & $\begin{array}{c}\text { (3) } \\
\text { Ranking of } \\
\text { scenarios }\end{array}$ \\
\hline Gradual retirement & $\begin{array}{c}1.005 * * \\
(0.480)\end{array}$ & $\begin{array}{c}-0.233 \\
(0.361)\end{array}$ & $\begin{array}{c}-1.852 * * \\
(0.727)\end{array}$ \\
\hline Male & $\begin{array}{c}0.099 \\
(0.089)\end{array}$ & $\begin{array}{c}0.098 \\
(0.089)\end{array}$ & $\begin{array}{c}0.057 \\
(0.050)\end{array}$ \\
\hline Male $*$ gradual retirement & $\begin{array}{c}0.049 \\
(0.061)\end{array}$ & $\begin{array}{l}0.084 * \\
(0.047)\end{array}$ & $\begin{array}{l}-0.113 \\
(0.099)\end{array}$ \\
\hline Age & $\begin{array}{l}-0.010 \\
(0.007)\end{array}$ & $\begin{array}{l}-0.010 \\
(0.007)\end{array}$ & $\begin{array}{c}0.004 \\
(0.004)\end{array}$ \\
\hline Age $*$ gradual retirement & $\begin{array}{c}-0.002 \\
(0.005)\end{array}$ & $\begin{array}{c}0.002 \\
(0.004)\end{array}$ & $\begin{array}{c}-0.007 \\
(0.008)\end{array}$ \\
\hline High education level (intermediate level $=$ ref) & $\begin{array}{c}-0.299 * * * \\
(0.095)\end{array}$ & $\begin{array}{c}-0.298 * * * \\
(0.095)\end{array}$ & $\begin{array}{c}-0.004 \\
(0.054)\end{array}$ \\
\hline High education level $*$ gradual retirement & $\begin{array}{c}-0.149 * * \\
(0.069)\end{array}$ & $\begin{array}{c}-0.028 \\
(0.050)\end{array}$ & $\begin{array}{c}0.005 \\
(0.109)\end{array}$ \\
\hline Low education level & $\begin{array}{c}0.107 \\
(0.216)\end{array}$ & $\begin{array}{c}0.106 \\
(0.216)\end{array}$ & $\begin{array}{c}0.164 \\
(0.126)\end{array}$ \\
\hline Low education level $*$ gradual retirement & $\begin{array}{c}-0.054 \\
(0.151)\end{array}$ & $\begin{array}{c}0.011 \\
(0.115)\end{array}$ & $\begin{array}{c}-0.329 \\
(0.247)\end{array}$ \\
\hline Wage & $\begin{array}{l}-0.014 \\
(0.096)\end{array}$ & $\begin{array}{l}-0.014 \\
(0.096)\end{array}$ & $\begin{array}{c}-0.121 * * * \\
(0.039)\end{array}$ \\
\hline Wage $*$ gradual retirement & $\begin{array}{c}0.035 \\
(0.051)\end{array}$ & $\begin{array}{l}-0.023 \\
(0.038)\end{array}$ & $\begin{array}{c}0.244 * * * \\
(0.077)\end{array}$ \\
\hline Married & $\begin{array}{c}-0.310 * * \\
(0.151)\end{array}$ & $\begin{array}{c}-0.308 * * \\
(0.151)\end{array}$ & $\begin{array}{c}-0.061 \\
(0.091)\end{array}$ \\
\hline Married $*$ gradual retirement & $\begin{array}{c}0.178^{*} \\
(0.106)\end{array}$ & $\begin{array}{c}0.091 \\
(0.079)\end{array}$ & $\begin{array}{c}0.116 \\
(0.183)\end{array}$ \\
\hline Partner with own income & $\begin{array}{c}-0.307^{*} \\
(0.159)\end{array}$ & $\begin{array}{c}-0.308^{*} \\
(0.158)\end{array}$ & $\begin{array}{c}0.042 \\
(0.091)\end{array}$ \\
\hline Partner with own income $*$ gradual retirement & $\begin{array}{l}-0.015 \\
(0.114)\end{array}$ & $\begin{array}{c}0.080 \\
(0.086)\end{array}$ & $\begin{array}{c}-0.077 \\
(0.183)\end{array}$ \\
\hline Partner works & $\begin{array}{c}0.073 \\
(0.122)\end{array}$ & $\begin{array}{c}0.071 \\
(0.122)\end{array}$ & $\begin{array}{l}-0.060 \\
(0.065)\end{array}$ \\
\hline Partner works $*$ gradual retirement & $\begin{array}{l}-0.027 \\
(0.086)\end{array}$ & $\begin{array}{l}-0.044 \\
(0.065)\end{array}$ & $\begin{array}{c}0.119 \\
(0.130)\end{array}$ \\
\hline Number of Sick days & $\begin{array}{c}-0.003 * * \\
(0.001)\end{array}$ & $\begin{array}{c}-0.003 * * \\
(0.001)\end{array}$ & $\begin{array}{c}0.000 \\
(0.001)\end{array}$ \\
\hline Number of Sick days $*$ gradual retirement & $\begin{array}{c}0.001 \\
(0.001)\end{array}$ & $\begin{array}{c}0.001 \\
(0.001)\end{array}$ & $\begin{array}{l}-0.000 \\
(0.001)\end{array}$ \\
\hline Life expectancy & $\begin{array}{c}0.007 * * * \\
(0.002)\end{array}$ & $\begin{array}{c}0.007 * * * \\
(0.002)\end{array}$ & $\begin{array}{c}0.003 * * \\
(0.001)\end{array}$ \\
\hline Life expectancy $*$ gradual retirement & $\begin{array}{l}-0.002 \\
(0.002)\end{array}$ & $\begin{array}{l}-0.002 \\
(0.001)\end{array}$ & $\begin{array}{c}-0.005 * * \\
(0.002)\end{array}$ \\
\hline Constant & $\begin{array}{c}66.413 * * * \\
(0.859)\end{array}$ & $\begin{array}{c}66.406 * * * \\
(0.859)\end{array}$ & $\begin{array}{c}4.427 * * * \\
(0.364)\end{array}$ \\
\hline Observations & 10,008 & 10,008 & 8,477 \\
\hline R-squared & 0.100 & 0.050 & 0.055 \\
\hline
\end{tabular}


Table 7: Gradual retirement and full-time-equivalent age of retirement, heterogeneity analysis on job characteristics

\begin{tabular}{|c|c|c|c|}
\hline VARIABLES & $\begin{array}{c}\text { (1) } \\
\text { Retirement age }\end{array}$ & $\begin{array}{c}\text { (2) } \\
\text { Fulltime } \\
\text { equivalent of } \\
\text { retirement age }\end{array}$ & $\begin{array}{c}\text { (3) } \\
\text { Ranking of } \\
\text { scenarios }\end{array}$ \\
\hline Gradual retirement & $\begin{array}{c}0.774 * * * \\
(0.081)\end{array}$ & $\begin{array}{c}-0.440 * * * \\
(0.063)\end{array}$ & $\begin{array}{c}-0.657 * * * \\
(0.147)\end{array}$ \\
\hline Routine tasks & $\begin{array}{c}0.006 \\
(0.015)\end{array}$ & $\begin{array}{c}0.006 \\
(0.015)\end{array}$ & $\begin{array}{c}0.012 \\
(0.009)\end{array}$ \\
\hline Routine tasks $*$ gradual retirement & $\begin{array}{c}0.011 \\
(0.010)\end{array}$ & $\begin{array}{c}0.008 \\
(0.008)\end{array}$ & $\begin{array}{l}-0.025 \\
(0.018)\end{array}$ \\
\hline Non-Routine tasks & $\begin{array}{l}-0.030^{*} \\
(0.016)\end{array}$ & $\begin{array}{l}-0.030^{*} \\
(0.016)\end{array}$ & $\begin{array}{l}-0.005 \\
(0.009)\end{array}$ \\
\hline Non-Routine tasks $*$ gradual retirement & $\begin{array}{c}0.026 * * \\
(0.011)\end{array}$ & $\begin{array}{c}0.018 * * \\
(0.009)\end{array}$ & $\begin{array}{c}0.010 \\
(0.018)\end{array}$ \\
\hline Constant & $\begin{array}{c}65.637 * * * \\
(0.121)\end{array}$ & $\begin{array}{c}65.637 * * * \\
(0.121)\end{array}$ & $\begin{array}{c}3.829 * * * \\
(0.074)\end{array}$ \\
\hline $\begin{array}{l}\text { Observations } \\
\text { R-squared }\end{array}$ & $\begin{array}{c}10,476 \\
0.068\end{array}$ & $\begin{array}{c}10,476 \\
0.010\end{array}$ & $\begin{array}{l}8,849 \\
0.051\end{array}$ \\
\hline
\end{tabular}

OLS estimates including robust standard errors corrected for clustering on the individual level in parentheses $* * * \mathrm{p}<0.01, * * \mathrm{p}<0.05, * \mathrm{p}<0.1$. 


\section{Appendix:}

Table A1: Background characteristics.

\begin{tabular}{lll}
\hline Characteristic & Average & $\begin{array}{l}\text { Standard } \\
\text { deviation }\end{array}$ \\
\hline Age & 56.12 & 5.70 \\
Gender (1 if male) & 0.62 & 0.48 \\
Married & 0.82 & 0.39 \\
High-educated & 0.72 & 0.44 \\
Low-educated & 0.04 & 0.20 \\
Log monthly wage & 7.73 & 0.54 \\
Partner with income & 0.71 & 0.45 \\
$\begin{array}{l}\text { Partner with work } \\
\text { Number of sick days }\end{array}$ & .57 & 0.50 \\
$\begin{array}{l}\text { Life expectancy (probability to reach } \\
\text { age 80) }\end{array}$ & 0.83 & 1.27 \\
Cognitive tasks (on a scale from 0-10) & 4.62 & 0.18 \\
Repetitive tasks (on a scale from 0-10) & 6.16 & 2.49 \\
\hline
\end{tabular}

Subjective life expectancy probabilities are measured by the following survey question: How large do you think is the chance that you will attain (at least) the age of 80 , where 0 means $0 \%$ change and 100 means $100 \%$ change? The extent to which employees perform routine or non-routine tasks is measured by the following survey questions: How often do you spend time on the following tasks in your job? You can give your answer on a scale from 0 until 10, where 0 means 'never' and 10 means 'always': Short repetitive tasks (fixed procedures etc.); Supervision of other employees; Solving problems for which it takes at least 30 minutes to come to an adequate solution. We take item 1 as an indicator for routine tasks, while our indicator of the extent to which employees perform non-routine tasks is based on the arithmetic average of items 2 and 3 . 
Table A2: Background characteristics by retirement scenario

\begin{tabular}{|c|c|c|c|c|c|c|c|c|c|c|c|}
\hline Characteristic & & & & & Percentage & & & & & & F-value \\
\hline & Scenario 1 & Scenario 2 & Scenario 3 & Scenario 4 & Scenario 5 & Scenario 6 & Scenario 7 & Scenario 8 & Scenario 9 & Scenario 10 & \\
\hline Age & 56.1 & 56.3 & 56.0 & 56.2 & 56.2 & 56.1 & 56.0 & 56.3 & 56.0 & 55.9 & 0.34 \\
\hline Gender ( 1 if male) & 0.62 & 0.61 & 0.61 & 0.63 & 0.63 & 0.62 & 0.60 & 0.62 & 0.63 & 0.62 & 0.47 \\
\hline Married & 0.72 & 0.71 & 0.71 & 0.74 & 0.73 & 0.72 & 0.71 & 0.71 & 0.73 & 0.73 & 0.37 \\
\hline Highly educated & 0.01 & 0.06 & 0.04 & 0.03 & 0.0 .4 & 0.04 & 0.05 & 0.04 & 0.04 & 0.04 & 0.68 \\
\hline Low-educated & 7.74 & 7.74 & 7.73 & 7.74 & 7.75 & 7.74 & 7.73 & 7.73 & 7.74 & 7.74 & 0.37 \\
\hline Log monthly wage & 0.81 & 0.81 & 0.80 & 0.83 & 0.83 & 0.82 & 0.80 & 0.81 & 0.82 & 0.82 & 0.09 \\
\hline Partner with income & 0.71 & 0.70 & 0.69 & 0.71 & 0.72 & 0.71 & 0.70 & 0.69 & 0.71 & 0.72 & 0.70 \\
\hline Partner with work & 0.57 & 0.57 & 0.56 & 0.57 & 0.58 & 0.57 & 0.57 & 0.57 & 0.57 & 0.58 & 0.48 \\
\hline Sick days & 1.11 & 1.13 & 1.110 & 1.13 & 1.12 & 1.11 & 1.08 & 1.15 & 1.08 & 1.07 & 0.18 \\
\hline $\begin{array}{l}\text { Life expectancy } \\
\text { (probability to reach } \\
\text { age } 80 \text { ) }\end{array}$ & 83.3 & 83.1 & 83.3 & 83.3 & 83.2 & 83.3 & 83.3 & 83.2 & 83.4 & 83.4 & 0.36 \\
\hline Cognitive tasks & 4.61 & 4.59 & 4.61 & 4.61 & 4.62 & 4.62 & 4.62 & 4.58 & 4.65 & 4.66 & 0.03 \\
\hline Repetitive tasks & 6.17 & 6.20 & 6.13 & 6.21 & 6.21 & 6.17 & 6.12 & 6.20 & 6.14 & 6.13 & 0.08 \\
\hline
\end{tabular}


Table A3: Basic model including individual fixed effects

\begin{tabular}{lcc}
\hline VARIABLES & $\begin{array}{c}(1) \\
\text { Retirement age }\end{array}$ & $\begin{array}{c}(2) \\
\text { Fulltime } \\
\text { equivalent of } \\
\text { retirement age }\end{array}$ \\
\hline Gradual retirement & & $-0.224 * * *$ \\
Price of leisure incentive & $0.964 * * *$ & $(0.023)$ \\
Gradual retirement* Price of leisure incentive & $(0.029)$ & $0.585 * * *$ \\
Pension income incentive & $0.591 * * *$ & $(0.016)$ \\
Gradual retirement*Pension income incentive & $(0.017)$ & $-0.079 * * *$ \\
& 0.021 & $(0.017)$ \\
Constant & $(0.026)$ & $0.467 * * *$ \\
& $0.462 * * *$ & $(0.015)$ \\
Individual fixed effects & $(0.015)$ & $-0.047 * * *$ \\
Observations & 0.004 & $(0.017)$ \\
R-squared & $(0.024)$ & $65.000^{* * *}$ \\
Number of individuals & $65.001 * * *$ & $(0.017)$ \\
\hline OLS estim & $(0.019)$ & Yes \\
\hline
\end{tabular}

OLS estimates including robust standard errors corrected for clustering on the individual level in parentheses $* * * \mathrm{p}<0.01, * * \mathrm{p}<0.05, * \mathrm{p}<0.1$. 
Table A4: The relationship between gradual retirement and retirement age: nonlinear

\begin{tabular}{|c|c|c|c|c|c|c|}
\hline $\begin{array}{l}\text { VARIABLES } \\
\text { Multinomial logit estimates: Retirement ages } 65 \\
\text { and } 66 \text { are ref. }\end{array}$ & $\begin{array}{c}(1) \\
\text { Early } \\
\text { retirement } \\
\text { (64 years or } \\
\text { younger) } \\
\end{array}$ & $\begin{array}{l}\text { (2) } \\
\text { Late retirement } \\
\text { (67) years or } \\
\text { older }\end{array}$ & $\begin{array}{c}(3) \\
\text { Early } \\
\text { retirement } \\
\text { (64 years or } \\
\text { younger) } \\
\end{array}$ & $\begin{array}{l}\text { (4) } \\
\text { Late retirement } \\
\text { 67) years or } \\
\text { older }\end{array}$ & $\begin{array}{c}(5) \\
\text { Early } \\
\text { retirement } \\
\text { (64 years or } \\
\text { younger) } \\
\end{array}$ & $\begin{array}{l}\text { (6) } \\
\text { Late retirement } \\
\text { 67) years or } \\
\text { older }\end{array}$ \\
\hline Gradual retirement & $\begin{array}{c}-0.236 * * * \\
(0.047)\end{array}$ & $\begin{array}{c}1.090 * * * \\
(0.043)\end{array}$ & $\begin{array}{c}-0.299 * * * \\
(0.050)\end{array}$ & $\begin{array}{c}1.123 * * * \\
(0.045)\end{array}$ & $\begin{array}{c}-0.593 * * * \\
(0.065)\end{array}$ & $\begin{array}{c}0.917 * * * \\
(0.066)\end{array}$ \\
\hline Price of leisure incentive & & & $\begin{array}{c}-0.761 * * * \\
(0.050)\end{array}$ & $\begin{array}{c}0.337 * * * \\
(0.029)\end{array}$ & $\begin{array}{c}-0.930 * * * \\
(0.054)\end{array}$ & $\begin{array}{c}0.181 * * * \\
(0.037)\end{array}$ \\
\hline Gradual retirement* Price of leisure incentive & & & & & $\begin{array}{c}0.480 * * * \\
(0.079)\end{array}$ & $\begin{array}{c}0.333 * * * \\
(0.054)\end{array}$ \\
\hline Pension income incentive & & & $\begin{array}{c}-0.392 * * * \\
(0.035)\end{array}$ & $\begin{array}{c}0.301 * * * \\
(0.028)\end{array}$ & $\begin{array}{c}-0.500 * * * \\
(0.043)\end{array}$ & $\begin{array}{c}0.280 * * * \\
(0.038)\end{array}$ \\
\hline Gradual retirement*Pension income incentive & & & & & $\begin{array}{c}0.288 * * * \\
(0.065)\end{array}$ & $\begin{array}{c}0.046 \\
(0.054)\end{array}$ \\
\hline Constant & $\begin{array}{c}-1.116^{* * * *} \\
(0.153)\end{array}$ & $\begin{array}{c}-0.575 * * * \\
(0.118)\end{array}$ & $\begin{array}{c}-0.528 * * * \\
(0.162)\end{array}$ & $\begin{array}{c}-0.954 * * * \\
(0.128)\end{array}$ & $\begin{array}{c}-0.418 * * \\
(0.162)\end{array}$ & $\begin{array}{c}-0.851 * * * \\
(0.132)\end{array}$ \\
\hline Observations & 10,560 & 10,560 & 10,560 & 10,560 & 10,560 & 10,560 \\
\hline
\end{tabular}

Coefficient estimates on which the marginal effects presented in Figure 2 are based. Robust standard errors corrected for clustering on the individual level in parentheses.

$* * * \mathrm{p}<0.01, * * \mathrm{p}<0.05, * \mathrm{p}<0.1$ 
Table A5: Ranking the scenarios: multinomial logit results

\begin{tabular}{|c|c|c|c|c|c|c|}
\hline & $(1)$ & $(2)$ & $(3)$ & $(4)$ & $(5)$ & $(6)$ \\
\hline & $\begin{array}{c}\text { Least } \\
\text { preferred } \\
\text { scenario }\end{array}$ & & & & & $\begin{array}{c}\text { Most } \\
\text { preferred } \\
\text { scenario }\end{array}$ \\
\hline \multicolumn{7}{|l|}{ Model 1} \\
\hline Gradual retirement & $\begin{array}{c}0.125^{* * * *} \\
(0.008)\end{array}$ & $\begin{array}{c}0.038 * * * \\
(0.008)\end{array}$ & $\begin{array}{c}0.040^{* * * *} \\
(0.008)\end{array}$ & $\begin{array}{c}-0.062 * * * \\
(0.008)\end{array}$ & $\begin{array}{c}-0.024 * * * \\
(0.008)\end{array}$ & $\begin{array}{c}-0.116^{* * *} * \\
(0.008)\end{array}$ \\
\hline \multicolumn{7}{|l|}{ Model 2} \\
\hline Gradual retirement & $\begin{array}{c}0.125 * * * \\
(0.008)\end{array}$ & $\begin{array}{c}0.039 * * * \\
(0.008)\end{array}$ & $\begin{array}{c}0.041 * * * \\
(0.008)\end{array}$ & $\begin{array}{c}-0.062 * * * \\
(0.008)\end{array}$ & $\begin{array}{c}-0.025^{* * *} \\
(0.008)\end{array}$ & $\begin{array}{c}-0.116^{* * * *} \\
(0.008)\end{array}$ \\
\hline Price of leisure incentive & $\begin{array}{c}0.171^{* * *} \\
(0.006)\end{array}$ & $\begin{array}{c}0.065^{* * * *} \\
(0.004)\end{array}$ & $\begin{array}{c}0.015 * * * \\
(0.004)\end{array}$ & $\begin{array}{c}-0.007 \\
(0.005)\end{array}$ & $\begin{array}{c}-0.061 * * * \\
(0.005)\end{array}$ & $\begin{array}{c}-0.184 * * * \\
(0.007)\end{array}$ \\
\hline Pension income incentive & $\begin{array}{c}0.179 * * * \\
(0.005) \\
\end{array}$ & $\begin{array}{c}0.080^{* * * *} \\
(0.004) \\
\end{array}$ & $\begin{array}{c}0.026 * * * \\
(0.004) \\
\end{array}$ & $\begin{array}{c}0.012 * * * \\
(0.005) \\
\end{array}$ & $\begin{array}{c}-0.064 * * * \\
(0.006) \\
\end{array}$ & $\begin{array}{c}-0.234 * * * \\
(0.010) \\
\end{array}$ \\
\hline
\end{tabular}




\section{Figure A1: Examples of the retirement vignettes}

We would like to know more about your retirement preferences. In the following six questions, we therefore confront you with different retirement schemes. Thereby, you always have to assume that you presently work full-time.

Some of these schemes only enable you to retire full-time, while other schemes enable you to first retire part-time for several years before you retire full-time (you always retire for half and have to continue work for half in these schemes until you fully stop working). It always holds that the earlier you retire, the lower your pension will be.

In each question, we present a table in which for each possible retirement age is shown how much pension you will receive from that age. The income is net (free disposable after taxes and benefits) and is expressed as a percentage of your current net wage. Your state old age pension (AOW) and the income from part-time work (in case of part-time retirement) are already included in the calculation. In the schemes in which you first retire part-time, you would receive this income during the period in which you are part-time retired and during the period thereafter. 


\section{Scenario 1}

If you could choose among these possibilities, at what age you prefer to stop working?

\begin{tabular}{|c|c|}
\hline Age of retirement & Replacement rate (as \% of net income) \\
\hline 62 & 60 \\
\hline 63 & 65 \\
\hline 64 & 70 \\
\hline 65 & 75 \\
\hline 66 & 80 \\
\hline 67 & 85 \\
\hline 68 & 90 \\
\hline 69 & 95 \\
\hline 70 & 100 \\
\hline
\end{tabular}

- Completely stop working at the age of 62 years at an income of $60 \%$

- Completely stop working at the age of 63 years at an income of $65 \%$

- Completely stop working at the age of 64 years at an income of $70 \%$

- Completely stop working at the age of 65 years at an income of $75 \%$

- Completely stop working at the age of 66 years at an income of $80 \%$

- Completely stop working at the age of 67 years at an income of $85 \%$

- Completely stop working at the age of 68 years at an income of $90 \%$

- Completely stop working at the age of 69 years at an income of $95 \%$

- Completely stop working at the age of 70 years at an income of $100 \%$ 


\section{Scenario 6}

If you could choose among these possibilities, at what age you prefer to stop working?

\begin{tabular}{|c|c|}
\hline Age of gradual retirement to full retirement & Replacement rate (as \% of net income) \\
\hline $62-63$ & 62.5 \\
\hline $62-64$ & 65 \\
\hline $63-64$ & 67.5 \\
\hline $63-65$ & 70 \\
\hline $62-67$ & 72.5 \\
\hline 64-65 & 72.5 \\
\hline 63-67 & 75 \\
\hline 64-66 & 75 \\
\hline $66-67$ & 77.5 \\
\hline $65-66$ & 77.5 \\
\hline $62-70$ & 80 \\
\hline $65-67$ & 80 \\
\hline 63-70 & 82.5 \\
\hline 66-67 & 82.5 \\
\hline $65-69$ & 85 \\
\hline $66-68$ & 85 \\
\hline 66-69 & 87.5 \\
\hline 67-68 & 87.5 \\
\hline 66-70 & 90 \\
\hline $67-70$ & 92.5 \\
\hline $68-70$ & 95 \\
\hline 69-70 & 97.5 \\
\hline
\end{tabular}

- Gradual retirement from 62 until 63, from 63years fully retired at a retirement income of $62.5 \%$

- Gradual retirement from 62 until 64, from 64years fully retired at a retirement income of $65 \%$

- Gradual retirement from 63 until 64, from 64years fully retired at a retirement income of $67.5 \%$

- Gradual retirement from 63 until 65, from 65years fully retired at a retirement income of $70 \%$

- Gradual retirement from 62 until 67, from 67years fully retired at a retirement income of $72.5 \%$

- Gradual retirement from 64 until 65, from 65years fully retired at a retirement income of $72.5 \%$

- Gradual retirement from 63 until 67, from 67years fully retired at a retirement income of 75\%

- Gradual retirement from 64 until 66, from 66years fully retired at a retirement income of 75\%

- Gradual retirement from 64 until 67, from 67years fully retired at a retirement income of $77.5 \%$

- Gradual retirement from 65 until 66, from 66years fully retired at a retirement income of $77.5 \%$

- Gradual retirement from 62 until 70, from 70years fully retired at a retirement income of $80 \%$

- Gradual retirement from 65 until 67, from 67years fully retired at a retirement income of $80 \%$

- Gradual retirement from 63 until 70, from 70years fully retired at a retirement income of $82.5 \%$

- Gradual retirement from 66 until 67, from 67years fully retired at a retirement income of $82.5 \%$

- Gradual retirement from 65 until 69, from 69years fully retired at a retirement income of $85 \%$

- Gradual retirement from 66 until 68, from 68years fully retired at a retirement income of $85 \%$

- Gradual retirement from 66 until 69, from 69years fully retired at a retirement income of $87.5 \%$

- Gradual retirement from 67 until 68, from 68years fully retired at a retirement income of $87.5 \%$

- Gradual retirement from 66 until 70, from 70years fully retired at a retirement income of $90 \%$

- Gradual retirement from 67 until 70, from 70years fully retired at a retirement income of $92.5 \%$

- Gradual retirement from 68 until 70, from 70years fully retired at a retirement income of $95 \%$

○ Gradual retirement from 69 until 70, from 70years fully retired at a retirement income of $97.5 \%$ 